\title{
Knowledge of the nursing personnel regarding ECT in a view to develop an informational booklet.
}

\author{
Aashish Parihar*, Himanshu Vyas**, Naveen Kumar Sharma*** \\ *, **, *** M.Sc. Nursing Tutor College of nursing, AIIMS, Jodhpur
}

\begin{abstract}
A study to assess the knowledge of nursing personnel regarding ECT in a view to develop an information booklet. The samples consisting of 50 nursing personnel were selected by purposive sampling technique. The tool comprise of 40 knowledge questionnaire which was given to subjects for their response. The data obtained were analyzed using descriptive and inferential statistics. Knowledge of nursing personnel was statistically significant at $P<.001$. This data help the researcher to develop an information booklet.
\end{abstract}

Key words: Nursing Personnel, Knowledge, ECT, Informational Booklet.

\section{Introduction}

According to Health Informatics of India, 2001, there are only 48 mental hospitals to serve a population of one billion. There are 2400-2600 qualified psychiatrists working in both private and public sectors, between 700-800 clinical psychologists, 200-300 qualified psychiatric social workers and 400-500 trained psychiatric nurses. The available total beds in India are less than $0.8 / 1000$ populations of which psychiatric bed constitute a shocking 0.032 which comes to one psychiatric bed for over 3200 population.

About 500 million people are believed to suffer from neurotic, stress and somatoform. A further 200 million people suffer from mood disorder such as chronic manic depression. Mental retardation affects about 83 million people, epilepsy 30 million, dementia 22 million and schizophrenia 16 million. In India surveys of mental morbidity carried out in various part of the country suggest a morbidity rate of not less than 18-20/1000 and the types of illnesses and their prevalence are very much the same as in the other part of the world.

All these data emphasized that the importance of mental health cannot be overlooked. Among the treatment modalities of psychiatric illnesses ECT is used more frequently as it was found to be effective over other methods. Adequate knowledge of skilled nurses in psychiatric setting is essentially required throughout the ECT for the effective care of the patients.

Although the syllabus of basic nursing courses covers the aspect of psychiatric nursing, evaluation of the future nurses on the aspect of ECT, both knowledge and practices is lacking. Therefore this study aims at presenting relevant data of the existing knowledge regarding ECT.

The psychiatric nurse is usually one of the first people a patient will see when he is admitted to a mental hospital. He or she will be monitoring most of the patient's plan of care and implementing doctors' orders. She will administer medications to the patient as ordered, as needed. As she takes care of the patient, she should be careful to chart every detail of her interactions with and observations of patients, as well as vital medical information, so that the doctor and other staff can make objective decisions concerning that patient's care, having been educated as to his progress, or lack thereof. She will most likely be reporting, in person, on the patient's care to both doctors and other nursing staff, as needed, for the best care possible.

Objectives of the research was to assess the knowledge of nursing personnel regarding ECT; To find out the relationship of Knowledge with the selected demographic variables like Age, Sex, Academic qualification, Professional qualification, Total clinical experience, Total clinical experience in psychiatric unit ; and to develop an informational booklet regarding ECT.

Variables in study were Independent and dependent. Independent variables were age, academic qualification, professional qualification, total clinical experience, and total clinical experience in psychiatric unit; and Dependent variable was knowledge of ECT. 
Descriptive survey approach and descriptive survey research design used in present study. Study was conducted at Govt. Psychiatric Centre, Jaipur, Rajasthan. The target population for the study was nursing personnel working in Govt. Psychiatric Centre, Jaipur, Rajasthan. For the final study a total of fifty (50) nursing personnel of Govt. Psychiatric Centre, Jaipur, Rajasthan were selected as sample. By probability sampling technique namely purposive sampling was used to make the study more practicable and feasible.

A self administered questionnaire was prepared to assess the knowledge of nursing personnel on ECT. The self administered structured questionnaire comprised of 40 items about ECT. Score $\geq 65$ considered as Adequate and score $<65$ considered as Inadequate.

\section{Result}

The obtained data were analyzed, tabulated and interpreted by employing descriptive and inferential statistics. The data analyses have been organized under three Sections. SECTION- 1: Description of demographic characteristics of nursing personnel. SECTION -2: Distribution of nursing personnel according to level of knowledge regarding ECT. SECTION -3: Description of knowledge with respect to the selected demographic variables of nursing personnel.

SECTION- 1

Table-I

Description of Demographic Characteristics of Nursing Personnel

\begin{tabular}{|c|c|c|c|c|}
\hline \multirow[t]{2}{*}{ S.No. } & \multirow[t]{2}{*}{ Demographic Variable } & \multirow[t]{2}{*}{ Category } & \multicolumn{2}{|c|}{ Respondents } \\
\hline & & & Number & Percentage \\
\hline \multirow[t]{3}{*}{1.} & \multirow[t]{3}{*}{ Age (Years) } & 21-30 & 15 & 30 \\
\hline & & $31-40$ & 17 & 34 \\
\hline & & $>40$ & 18 & 36 \\
\hline \multirow[t]{2}{*}{2} & \multirow[t]{2}{*}{ Sex } & Male & 37 & 74 \\
\hline & & Female & 13 & 26 \\
\hline \multirow[t]{2}{*}{3} & \multirow{2}{*}{ Academic Qualifications } & Under Graduate & 12 & 24 \\
\hline & & Below Graduate & 38 & 76 \\
\hline \multirow[t]{2}{*}{4} & \multirow[t]{2}{*}{ Professional Qualifications } & GNM & 37 & 74 \\
\hline & & B.Sc. Nursing & 13 & 26 \\
\hline \multirow[t]{2}{*}{5} & \multirow[t]{2}{*}{ Total Clinical Experience } & $\leq 15$ & 35 & 70 \\
\hline & & $>15$ & 15 & 30 \\
\hline \multirow[t]{2}{*}{6} & \multirow[t]{2}{*}{ Total Clinical Experience in Psychiatric Unit } & $\leq \mathbf{5}$ & 32 & 64 \\
\hline & & $>5$ & 18 & 36 \\
\hline
\end{tabular}

SECTION -2

Table-II

Distribution of nursing personnel according to level of knowledge

\begin{tabular}{|l|l|l|l|}
\hline S.No. & Level of Knowledge & Respondents & $\mathbf{N}=\mathbf{5 0}$ \\
\cline { 3 - 4 } & & Number & Percentage \\
\hline 1. & Adequate & $\mathbf{2 6}$ & $\mathbf{5 2}$ \\
\hline 2 & Inadequate & 24 & 48 \\
\hline Total & & 50 & 100 \\
\hline
\end{tabular}

SECTION -3

Table-III

Description of knowledge with respect to the selected demographic variables of nursing personnel $(\mathrm{N}=\mathbf{5 0})$

\begin{tabular}{|l|l|l|l|l|}
\hline \multirow{2}{*}{$\begin{array}{l}\text { DEMOGRAPHIC } \\
\text { VERLES }\end{array}$} & $\begin{array}{l}\text { MEAN } \pm \text { SD OF LEVEL OF } \\
\text { KNOWLEDGE }\end{array}$ & P-VALUE & SIGNIFICANCE \\
\cline { 2 - 3 } & Adequate & Inadequate & & \\
\hline SEX & & & & \\
\hline Male & $28.90 \pm 2.67$ & $22.12 \pm 2.44$ & $<.001$ & HS \\
\hline Female & $28.20 \pm 2.04$ & $19.87 \pm 3.48$ & $<.001$ & HS \\
\hline P-value & $>.05$ & $>.05$ & & \\
\hline Significance & NS NS & NS & & \\
\hline $\begin{array}{l}\text { ACADEMIC } \\
\text { QUALIFICATION }\end{array}$ & & & \\
\hline Under graduate & $26.71 \pm 1.03$ & $21.20 \pm 4.01$ & $<.01$ & Sig \\
\hline
\end{tabular}




\begin{tabular}{|c|c|c|c|c|}
\hline Graduate \& above & $29.53 \pm 2.56$ & $21.42 \pm 2.70$ & $<.001$ & $\mathrm{HS}$ \\
\hline P-value & $<.01$ & $>.05$ & & \\
\hline Significance & Sig & NS & & \\
\hline \multicolumn{5}{|c|}{$\begin{array}{l}\text { PROFESSIONAL } \\
\text { QUALIFICATION }\end{array}$} \\
\hline GNM & $27.74 \pm 1.77$ & $20.72 \pm 3.19$ & $<.001$ & HS \\
\hline BSc Nursing & $31.57 \pm 2.32$ & $23.33 \pm 0.94$ & $<.001$ & HS \\
\hline P-value & $<.001$ & $>.05$ & & \\
\hline Significance & HS & NS & & \\
\hline \multicolumn{5}{|c|}{$\begin{array}{l}\text { LENGTH OF SERVICE (IN } \\
\text { YRS) }\end{array}$} \\
\hline$\leq 15$ & $29.12 \pm 2.91$ & $20.83 \pm 3.04$ & $<.001$ & $\mathrm{HS}$ \\
\hline$>15$ & $28.11 \pm 1.59$ & $23.00 \pm 2.31$ & $<.01$ & Sig \\
\hline P-value & $>.05$ & $>.05$ & & \\
\hline Significance & NS & NS & & \\
\hline \multicolumn{5}{|c|}{$\begin{array}{l}\text { EXPERIENCE } \\
\text { PSYCHIATRY } \\
\text { (IN YRS) }\end{array}$} \\
\hline$\leq 5$ & $28.60 \pm 2.92$ & $20.94 \pm 2.84$ & $<.001$ & HS \\
\hline$>5$ & $29.00 \pm 2.00$ & $22.42 \pm 3.20$ & $<.001$ & Sig \\
\hline P-value & $>.05$ & $>.05$ & & \\
\hline Significance & NS & NS & & \\
\hline
\end{tabular}

Above table depict that knowledge with respect to the selected demographic variables of nursing personnel was not significant at $>.05 \mathrm{P}$ value but significant at $<.01 \mathrm{P}$ value and highly significant at $<.001$.

\section{Discussion}

In the present study majority of nursing personnel 18 [36.00\%] were in the age group $41+$ years and 15 [30.00\%] were in age group of 21-31years; In the aspect of sex 37 [74.00\%] were male and only 13 [26.00\%] were female; Majority of subjects 37 [74.00\%] were under graduate and 13 [26.00\%] were graduate and above; $37[74.00 \%]$ were have GNM, 13[26.00\%] were have B.Sc. nursing as their professional qualification; 35 [70.00\%] were have less than or equal to 15 years of total clinical experience, whereas remaining 15 [30.00\%] have crossed the 15 years as their total clinical experience; 32 [64.00\%] have less than or equal to 5 years of clinical experience in psychiatric unit and remaining 18 [36.00\%] have more than 5 years of clinical experience in psychiatric unit.

Majority of the nursing personnel i.e. 26 [52.00\%] obtained adequate knowledge and remaining $24(48.00 \%)$ obtained inadequate knowledge. There is no significant association between knowledge of nursing personnel regarding ECT and demographic variables.

There is no significant relationship between mean knowledge score of nursing personnel with the sex at the level of 0.05 significance. But there is a high significant relationship between adequate and inadequate knowledge in both male and female respectively at the level of .001 .

There is significant relationship between mean knowledge score of adequate knowledge of nursing personnel and the academic qualification at the level of 0.01 significance. There is a significant relationship between adequate and inadequate knowledge of under graduate at the level of .01. There is high significant relationship between the adequate and inadequate mean knowledge score at the level of .001. There is high significant relationship between mean knowledge score of adequate knowledge of nursing personnel and professional qualification at the level of .001 significance. There is a high significant association between adequate mean 
knowledge score and inadequate mean knowledge score in both GNM and B.Sc. nursing at the level of .001 significance. There is no significant relationship between mean knowledge score of nursing personnel and the total clinical experience at the level of 0.05 significance. There is a high significant association between mean adequate knowledge and inadequate knowledge score whose total clinical experience is equal to or less than 15 years at the level of .001significance. A significant relationship between adequate and inadequate mean score whose total clinical experience is more than 15 years at the level of .01significance. There is no significant relationship between mean knowledge score of nursing personnel and the total clinical experience in psychiatric unit at the level of 0.05 significance. There is a high significant association between mean adequate knowledge and inadequate knowledge score whose total clinical experience in psychiatric unit is equal to or less than 5 years at the level of .001 significance. A significant relationship between adequate and inadequate mean score whose total clinical experience in psychiatric unit is more than 5 years at the level of .01significance.

\section{Nursing Implications}

\section{Nursing Education:}

Nursing services must be reoriented to enable prospective nurses to be well prepared to assist clients to develop their self-care potentials. This will help in achieving the goal of "Health for All". In the present curriculum of nursing, there is a provision of better psychiatric nursing care and various treatment modalities. It has to be emphasized and continued. The students should develop adequate knowledge and skills to provide better nursing care to the psychiatric patients who will receive ECT or any other treatment modalities.

Nursing educators should take responsibility of organizing continuing education programs for psychiatric nurses or nursing personnel who are working in psychiatric centre. In-service education program for practicing nurses must be conducted because it is sensitive issue with long term consequence on health of the people as well as the Nation.

\section{Psychiatric Nursing practice:}

Psychiatric- mental health nursing has evolved into a unique discipline, combining the knowledge, experience and skills of nursing and the biological and behavioral sciences. It offers a wide range of preventive and intervention strategies to promote optimal functioning and health.

ECT plays a vital role in treating majority of psychiatric illnesses like psychotic and neurotic illnesses. Nurses play a significant role in this mode of treatment. Her role extends from the time period continues throughout the following period of hospitalization. Thus it is crucial for nurses to be effective, skilled and knowledgeable throughout all the phases of treatment.

\section{Nursing administration}

Nurse administrator should take the initiative in organizing in-service continuing education program for nursing personnel regarding ECT which enables them to update their knowledge and acquire skill for ECT, and need to understand their initiating and maintaining behavioral change by constant supervision. Nurse administrator need to motivate the nursing personnel to provide better nursing to the patients who received ECT and she should make the rotation policy for appointing the nursing personnel in ECT room to provide better exposure of ECT to nursing personnel.

\section{Nursing research:}

Nursing research should be directed to further explore and update knowledge of nursing personnel regarding ECT. We need to have regular surveys or studies on large samples of nursing personnel to identify their knowledge regarding ECT. Studies can be conducted not only on nursing personnel but also on general population to assess their awareness regarding ECT. This can enhance quality of nursing services in psychiatric setting. Research should be encouraged to assess the impact of media on general population regarding ECT.

\section{Referance}

[1]. Abdellah, F.G., et al, Better Patient Care Through Nursing Research, $2^{\text {nd }}$ Edition, New York, Mac Millan Company, 1979

[2]. Fox, Devids J. Fundamental Of Research In Nursing, New York, Appleton Country, Crobts, 1970

[3]. K Park, 2007, Text Book Of Preventive And Social Medicine, 19 ${ }^{\text {th }}$ Edition, Jabalpur, Banarsi Das Behnot Publisher, pp644-649

[4]. Kerlinger, Fred N., Foundations and Behavioral research, $2^{\text {nd }}$ Edition, Delhi; Surjeet Publication, 1983

[5]. Potter P.A. and Perry, A.G. Foundation of Nursing, $5^{\text {th }}$ Edition Mosby Company, St. Lois, 2004

[6]. Pollit P.F. and Hungler, B.P. Nursing Research, Principle \& Methods, $6^{\text {th }}$ Edition, Philadelphia, Lippincott, 1999

[7]. Treece, E.W \& Treece, J.W., Elements of Research in Nursing, $4^{\text {th }}$ Edition, St. Lois, CV Mosby Company, 1986

[8]. BT Basvanthappa, 2008, Nursing research, $2^{\text {nd }}$ Edition, 2008, Jaypee Brothers, Medical Publishers (P) Ltd., New Delhi, p224

[9]. Ahuja Neeraj, A Short Textbook of Psychiatry, New Delhi, Jaypee Brothers Medical Publishers (P) Ltd., $6^{\text {th }}$ edition (2006) pp 178181 . 
[10]. Mary C.Townsend, Psychiatric Mental Health Nursing, Jaypee Brothers Medical Publishers (P) Ltd., $5^{\text {th }}$ edition, pp314-321

[11]. J N Vyas, Niraj Ahuja, Text book of Postgraduate Psychiatry, Jaypee Brothers Medical Publishers (P) Ltd., $2^{\text {nd }}$ edition, pp773-782

[12]. Dr. LP Shah, Handbook of Psychiatry, Vora medical publication, Bombay, $2^{\text {nd }}$ edition, pp91-95

[13]. Stuart W.Gail, Laria T. Michele; principle and practice of psychiatric nursing; $6^{\text {th }}$ edition; mosby publication; $\mathrm{p} 634-640$

[14]. J Kishore, National health programs of india, Century publication, New Delhi, $7^{\text {th }}$ edition, pp374-389

\section{JOURNALS:}

[15]. Andrade, Chittaranjan MD; Shah, Nilesh DPM, MD, DNB; Venkatesh, Basappa K. DPM, The Depiction of Electroconvulsive Therapy in Hindi Cinema, Journal of ect, March 2010, Volume 26, pp 16-22

[16]. James, Bawo O. , Morakinyo, Olufemi ,Lawani, Ambrose O. Omoaregba, , “Unmodified Electroconvulsive Therapy :The Perspective of Patients From a Developing Country", Journal of ECT, 2009

[17]. Ronald L. Warnell, M.D., Anthony D. Duk, M.D., George W. Christison, M.D. and Mark G. Haviland, Ph.D., "Teaching Electroconvulsive Therapy to Medical Students: Effects of Instructional Method on Knowledge and Attitudes", Journal of Acad Psychiatry, Vol.-29, December 2005, pp 433-436.

[18]. Kathryn M. Gaylord, RN, CS, MSN, "Parkinson's Disease and Electroconvulsive Therapy: A Nursing Perspective", Journal of the American Psychiatric Nurses Association, 2003, Vol. 9, pp 9-16

[19]. Mary Chambersea, Veslemoy Guisea, "Nurses attitudes to mental illness: A comparison of a sample of nurses from five European countries", International Journal of Nursing Studies, March 2010, Vol- 47, pp 350-362.

[20]. Arthur Williams, "A study to identify the needs of family members who were providing care to clients receiving outpatient ECT", American Journal of Psychiatric Nursing, 2010, Vol.- 12, pp12-29.

[21]. Kavanagh A., “A study regarding ECT and Nursing care”, International Journal of Nursing Studies, 2009, Vol. - XII-2, pp34-45

[22]. Akarn \& Best, "A study to assess the effect of education about electroconvulsive therapy on nursing practice and patients' satisfaction", International Journal of nursing studies, 2008, Vol.-X-12, pp11-19

[23]. Wood, “A study to explore nurses' knowledge of and attitude to ECT ", Journal of ECT, 2007, Vol.-6, pp56-58

[24]. Gass JP, “A study to assess the knowledge and attitude of Nurses regarding ECT”, International Journal of Nursing Studies, 1998, Vol.- VII, pp 4-10

[25]. Elizabeth, “A study to assess nursing students' perception of ECT after instruction with An ECT videotape", American Journal of Psychiatry, 1985, Vol.- 7, pp12-15.

\section{WEBSITES}

1. www.who.int

2. www. scielosp. com

3. www. medline. net

4. www. ncbi. com

5. www. pubmed. com

6. www. cdc. Gov

7. www.ect.org

8. www.mentalhealth.org

9. www.righthealth.com 